\title{
Konsep Perkembangan Kognitif Perspektif Al-Ghazali Dan Jean Piaget
}

\author{
Yahya AD \\ Universitas Islam Negeri Raden Intan Lampung \\ yahyaad@radenintan.ac.id
}

Submitted: 05-10-2018, Revised : 24-11-2018, Accepted : 24-12-2018

\begin{abstract}
The equation of cognitive development (reason) according to Al-Ghazali and Jean Piaget is found at the stages of development which are divided into four stages. In addition, the views of the two figures also have a relationship or meeting point found in the aspects of the ability of each stage that is passed in each process of cognitive development (reason). Differences in cognitive development (reason) according to Al-Ghazali and Jean Piaget are found in the methodology as the basis of both thoughts. the research method used is a philosophical comparative method, so the systematic discussion follows the following patterns or stages: 1) describes the concept of each character, 2) displays each concept, then compares it, 3) looks for and finds distinctive characteristics, including the similarities and differences of each of the two thoughts, and 4) conducting a critical evaluation of these two thoughts. Al-Ghazali based his thinking on ratios derived from revelation while Jean Piaget laid his rationale on pure ratios. In addition, there are also differences in the views of both of them in the use of the term, Al-Ghazali uses the term sense while Jean Piaget uses the term cognitive. Keywords: Intellect; Al-Ghazali; Jean Piaget; Cognitive Development
\end{abstract}

\begin{abstract}
Abstrak: Persamaan perkembangan kognitif (akal) menurut Al-Ghazali dan Jean Piaget yakni terdapat pada tahapan perkembangan yang terbagi kedalam empat tahapan. Selain itu, pandangan kedua tokoh juga mempunyai hubungan atau titik temu yang terdapat pada aspek kemampuan dari tiap tahapan yang dilewati dalam tiap proses perkembangan kognitif (akal). Perbedaan perkembangan kognitif (akal) menurut Al-Ghazali dan Jean Piaget terdapat pada metodologi sebagai basis pemikiran keduanya. metode penelitianyang digunakan adalah metode komparatif filosofis, maka sistematika pembahasannya mengikuti pola atau tahapan-tahapan sebagai berikut: 1) mendeskripsikan konsep dari masing-masing tokoh, 2) melakukan display dari masing-masing konsep, kemudian membandingkannya, 3) mencari dan menemukan ciri khas, termasuk persamaan dan perbedaan dari masingmasing pemikiran keduanya, dan 4) melakukan evaluasi kritis terhadap kedua pemikiran tersebut. Al-Ghazali mendasari pemikirannya pada rasio yang bersumber dari wahyu sedangkan Jean Piaget meletakkan dasar pemikirannya pada rasio murni. Selain itu juga perbedaan pandangan keduanya terdapat pada penggunaan istilah, Al- Ghazali menggunakan istilah akal sedangakan Jean Piaget menggunakan istilah kognitif.
\end{abstract}

Kata Kunci: Akal; Al-Ghazali; Jean Piaget; Perkembangan Kognitif

\section{Pendahuluan}

Konsep secara etimologis berarti "rancangan, ide, gambaran tentang suatu objek atau pengertian yang diikhtisarkan dari peristiwa konkret"(Bahasa, 2005). Ditinjau dari sudut epitemologi, konsep bermakna "simbol-simbol yang digunakan untuk memaknai fenomena tertentu"(Ihalauw, 2008). Sedangkan perkembangan yang dalam bahasa Inggrisnya dikenal dengan istilah development yang berarti "perubahan yang berkesinambungan dan progresif dalam organisme, dari lahir sampai mati"(Chaplin, 1997). Adapun istilah perkembangan yang dimaksud dalam artikel ini adalah developmental level, yaitu "tingkat perkembangan berdasarkan pembagian masa kehidupan (organisme atau individu) menurut jarak kronologis tertentu, yang berubah-ubah secara ajek".

Sedangkan istilah kognitif dari kata cognition (ingg) berarti "pengenalan, kesadaran, pengertian, dan merupakan konsep umum yang mencakup aktivitas-aktivitas seperti berpikir, memahami dan menalar"'(Reber \& Reber, 2010). Dengan kata lain, merupakan proses-proses psikologis yang melibatkan upaya dalam memperoleh, menyusun, dan menggunakan pengetahuan. Jadi secara keseluruhan arti dari konsep perkembangan kognitif, yaitu, suatu rancangan atau gambaran yang menggunakan simbol-simbol untuk melihat pola perubahan dari proses-proses psikologis yang terlibat dalam memperoleh, menyusun dan menggunakan 
pengetahuan dalam tiap fase perkembangan kehidupan manusia, menurut pandangan AlGhazali dan Jean Piaget.

Kedewasaan, pengalaman fisik, pengalaman logika, transmisi sosial dan pengaturan sendiri dipengaruhi oleh tingkatan perkembangan intelektual manusia. Proses perkembangan kognitif anak yang relevan salah satunya berdasarkan teori Piaget, karena dengan menggunakan teori tersebut, manusia mendapatkan informasi adanya tahap-tahap perkembangan tertentu pada kemampuan berpikir anak di levelnya, maka bila dikaitkan dengan pembelajaran dapat memberikan perlakuan yang tepat bagi anak, seperti memilih cara penyampaian materi bagi siswa sesuai dengan tahap perkembangan kemampuan berpikir yang dimiliki oleh anak(Ibda, 2015).

Berdasarkan Piaget seseorang mengalami perkembangan dari lahir sampai dewasa dibedakan menjadi empat tahap, pertama tahap sensorimotor yang terjadi sejak anak lahir sampai berumur 2 tahun, kedua tahap praoperasi pada umur 2 sampai 7 tahun, ketiga tahap operasi konkret pada umur 7 sampai 11 tahun, dan keempat tahap operasi formal setelah 11 tahun keatas. Perkembangan tersebut berurutan karena setiap tahap memerlukan tahap yang sebelumnya. Awal dan perkembangan tahap-tahap tersebut dapat berbeda untuk setiap pribadi(Suparno, 2001).

Al-Ghazali memiliki konsep pendidikan anak yang holistik yaitu mencakup aspek spiritual, moral, sosial, kognitif dan fisik. Tujuan pendidikannya pun tidak terbatas pada taqorrub ila Allah tapi juga pengembangan potensi jasmani dan rohani, karena Al-Ghazali memandang anak sebagai pribadi yang dilahirkan dengan potensi-potensinya dan mempunyai kecenderungan fitrah ke arah baik dan buruk sehingga sangat memerlukan pendidikan. Adapun materi pendidikan anak yang ditetapkan Al-Ghazali adalah berdasarkan aspek-aspek pendidikan yang dirumuskannya. Sedangkan metode pendidikan yang ditetapkannya adalah bervariasi dan tentunya hal itu disesuaikan dengan periodisasi anak(Janna, 2013). Al-Ghazâlî menganjurkan dalam membahas belajar untuk memanusiakan manusia dalam pembelajaran yang dilakukan seumur hidup, mencari ridla Allah, konsentrasi dalam belajar, dan mensucikan jiwa dalam belajar. Sedangkan dalam hal mengajar al-Ghazâlî menekankan fungsi guru dalam mengajar sebagai tauladan, motivator, pembimbing, dan mengajar dengan penuh kasih sayang(Solichin, 2006).

Begitu pentingnya fungsi dan peran akal bagi manusia, sangatlah wajar jika para ahli banyak yang tertarik untuk mengkaji seluk beluk akal. Sebut saja diantaranya Imam Al-Ghazali dan Jean Piaget. Untuk mengetahui lebih jauh tentang konsep-konsep akal menurut pandangan kedua tokoh tersebut, maka penulis tertarik untuk mengkaji lebih dalam pemikiran kedua tokoh tersebut melalui penelitian kepustakaan (Library Research), jenis studi naskah dengan fokus kajian tentang pemikiran kedua tokoh dimaksud. Sebagai studi pemikiran tokoh, maka langkah pertama yang dilakukan adalah menentukan objek material kajian yang dibatasi khusus pada konsep perkembangan akal menurut pandangan kedua tokoh dimaksud. Sedangkan objek formalnya, dilakukan melalui perspektif psikologis dan keagamaan. Tahap kedua, ditentukan metode dan teknik pengumpulan datanya, melalui sumber data primer dan sekunder dengan metode dokumentasi dengan menelusuri sumber-sumber data yang pernah ditulis oleh tokoh yang bersangkutan (data primer) dan atau sumber-sumber yang pernah ditulis oleh orang lain (data sekunser).

\section{Metode}

Sesuai dengan metodologi penelitian (kajian) yang digunakan, yakni metode komparatif filosofis, maka sistematika pembahasannya mengikuti pola atau tahapan-tahapan sebagai berikut: 1) mendeskripsikan konsep dari masing-masing tokoh, 2) melakukan display dari masing-masing konsep, kemudian membandingkannya, 3) mencari dan menemukan ciri khas, termasuk persamaan dan perbedaan dari masing-masing pemikiran keduanya, dan 4) 
melakukan evaluasi kritis terhadap kedua pemikiran tersebut, kemudian disimpulkan.

Namun sebelum langkah-langkah metodologis tersebut dilakukan, terlebih dahulu dikemukakan sekilas sejarah hidup masing-masing tokoh yang bandingkan untuk mengetahui faktor-faktor latar belakang keilmuan dan aspek-aspek sosial budaya yang turut memengaruhinya. Dengan demikian, akan memudahkan untuk menggambarkan sisi-sisi keunggulan maupun kelemahannya.

\section{Hasil dan Pembahsan}

\section{A. latar belakang kehidupan Al-Ghazali}

Al-Ghazali memiliki nama lengkap Abu Hamid Muhammad bin Muhammad al-thusi lahir pada $450 \mathrm{H} / 1058 \mathrm{M}$ di thus. Lingkungan pertama yang membentuk kesadaran Al-Ghazali adalah lingkungan keluarganya sendiri.Ayahnya tergolong orang yang hidup sederhana dan memiliki semangat keagamaan yang tinggi. Disebutkan bahwa ayahnya menyukai ulama, sehingga ia sangat mengharapkan anak- anaknya menjadi seorang ulama. Ketika ajalnya tiba, ia menitipkan Al-Ghazali dan Ahmad saudaranya ketika masih kecil ke seorang temannya, Seorang sufi yang hidup sangat sederhana.Suasana rumah sufi ini menjadi lingkungan kedua yang turut membentuk kesadaran Al-Ghazali, diperkirakan ia tinggal sampai usia lima belas tahun $(450-465 \mathrm{H})$.

Ketika sufi yang mengasuhnya merasa tidak mampu lagi memenuhi kebutuhan mereka ia menganjurkan agar mereka dimasukan ke sekolah, untuk memperoleh selain ilmu pengetahuan, santunan seperti lazimnya ketika itu. Antara tahun 465-470 H Al-Ghazali belajar ilmu fiqh dan ilmu dasar yang lainnya dari Ahmad al-Radzkani di Thus dan al-Ismaieili di jurjan. Selanjutnya pada $473 \mathrm{H}$, ia pergi ke Naisabur untuk belajar di madrasah al-Nizamiyah dan berguru kepada al- Juwaini Imam al-Haramain. Dari al-Juwaini ia belajar ilmu kalam dan manthiq. Kecerdasannya membuat ia cepat popular diantara teman-temannya. Bahkan diceritakan al-juwaini menyembunyikan keiriannya terhadap kecerdasan Al- Ghazali. Pada tahun 484 H/1091 M, dia diutus oleh Nizam Al-Mulk untuk menjadi guru besar di Madrasah Nizhamiyah, yang didirikan di Bagdad. Al-Ghazali menjadi salah satu orang yang paling terkenal di bagdad, dan selama empat tahun dia memberi kuliah kepada peserta yang mencapai lebih dari tiga ratus mahasiswa. Apabila diperhatikan, bidang-bidang ilmu yang diperolehnya sampai meninggalnya al-Juwaini tahun $478 \mathrm{H}$, terdiri atas bidang-bidang yang secara metodelogis berbeda. Ilmu fiqh dan ushul al-figh adalah ilmu-ilmu yang dirancang untuk kepentingan pelaksanaan ajaran-ajaran islam secara formal, dan pendekatannya jelas sangat formalistis. Ilmu Kalam bertujuan untuk menanamkan dasar-dasar akidah dan sekaligus mempertahankannya. Pendekatannya, meskipun menggunakan Kitab Suci dan Hadist sebagai rujukan, adalah bersifat rasional.Artinya, pada praktek akallah yang menjadi kriterium kebenaran dalam memahami makna ayat-ayat Kitab Suci dan Hadist tersebut dalam banyak hal. Selain ilmu kalam, ia juga belajar manthiq, yang tidak diragukan lagi rasionalitasnya. Maka sampai disini, Al-Ghazali sudah mempelajari setidak-tidaknya tiga sistem pemahaman keagamaan yang tidak saja berberda, tetapi juga secara metodologis bertentangan, yaitu: yang formalis, yang rasional dan yang intuitif.

Pandangan-pandangannya yang berkenaan dengan manusia, kelihatan bahwa meskipun ia menentang pandangan-pandangan para filosof, ia juga banyak mengambil pandanganpandangan para filosof terutama Ibnu Sina. Definisi jiwa (al- nafs) yang ditulisnya dalam $M a$ "arij al-Quds, dan pembagiannya kepada jiwa vegetative (al-nafs al-nabatiyyat), jiwa sensitive (al-nafs al-hawaniyyat) dan jiwa manusia (al-nafs al-insyaniyyat) hampir tidak berbeda dengan yang dibuat Ibnu Sina di dalam bukunya al-Najat. Demikian pula hal nya dengan pembagian akal kepada akal teoritis (al-a"ql al-nazhari) dan akal praktis (al-a" $q l$ al„,amali). Sumber lain yang turut memberikan sumbangan kepada pemikiran Al-Ghazali adalah pandangan dan pengalaman para sufi. Diantara mereka yang secara langsung disebut Al- 
Ghazali adalah Abu Thalib al-Makki, al-Junaid al-Baghdadi, al-Syibli Abu Yazid al-Busthami dan al-Muhasibi. Pandangan tasawwuf yang paling utama tampak pada Al-Ghazali adalah penempatan al-dzawq diatas akal. Pengutamaan al-dzawq ini diikuti sikapnya yang memperkecil arti kehidupan dunia bagi manusia dalam upaya mencapai kesempurnaan diri. Ia menyebut al-faqr (kemiskinan), al-ju" (lapar), al- khumul (lemah,lesu), al-tawakkul (kepasrahan) sebagai keutamaan-keutamaan. Tingkat al-tawakkul yang paling tinggi adalah tingkat para khawash (orang-orang khusus).

Pandangannya yang lain yang bersumber dari para filosof adalah logika dan etika. Didalam al-Munqidz, ia menyatakan bahwa logika termasuk kedalam kelompok ilmu yang semestinya tidak diingkari, sebab tidak ada hubungannya dengan keimanan. Sikap Al-Ghazali terhadap logika, pada dasarnya sama dengan sikapnya terhadap etika yang meliputi pembahasan pada sifat-sifat jiwa, akhlak, jenis-jenis dan pembagian, serta cara-cara memperbaiki dan menyempurnakannya.

\section{B. Latar Belakang Kehidupan Jean Piaget}

Sedangkan Kehidupan Jean Piaget dan Sumber Pemikirannya Jean Piaget dilahirkan di Neuchatel, Swiss pada tanggal 9 Agustus 1896. Ayahnya Arthur Piaget, adalah seorang professor sastra abad tengah yang sangat menyenangi sejarah local. Sementara Ibunya, Rebecca Jackson adalah seorang wanita yang cerdas dan penuh semangat namun menurut Jean sendiri ibunya sedikit mengidap neurotik. Kesan inilah yang membuat dia tertarik dengan disiplin psikologi, tetapi tidak dengan patologi. Sebagai anak sulung, dia agak bebas menentukan keinginannya. Ketika masih anak-anak dia sangat tertarik dengan ilmu alam, salah satu kesenangannya adalah mengumpulkan tulang kerangka burung-burung kecil. Dia menerbitkan makalah pertamanya ketika berusia 10 tahun, salah satu halamannya memaparkan penelitiannya tentang kerangka burung gereja albino.

Ketika remaja, dia mengalami krisis keyakinan. Karena didorong oleh ibunya yang selalu menekankan ajaran-ajaran religious, dia merasa argument-argumen religious terlalu kekanakkanakan. Setelah mempelajari filsafat dan logika, dia kemudia memutuskan untuk mengabdikan hidupnya demi menemukan penjelasan- penjelasan biologis tentang pengetahuan. Akhirnya, karenanya filsafat gagal membantunya dalam melaksanakan penelitian-penelitian ini, dia beralih ke psikologi. Setelah lulus sekolah menengah, dia melanjutkan pendidikan ke University of Neuchatel. Karena terlalu memaksakan diri belajar dan menulis, dia mengalami sakit parah dan disarankan untuk istirahat kepegunungan selama setahun. Ketika kembali ke Neuchatel, dia memutuskan untuk menuliskan filosofi hidupnya.Peristiwa inilah yang kemudian menjadi titik pusat seluruh karya dan perjalanan hidupnya.

Kedudukan baru sebagai ayah, membuka bidang pengalaman yang baru dan melahirkan kemungkinan-kemungkinan tak terduga bagi seorang psikolog anak. Bersama istrinya, Piaget sebagai biograf mengadakan observasi dan eskperimen psikologis setiap hari bersama ketiga anaknya. Perkembangan pemikiran Jean Piaget dipengaruhi oleh seorang sarjana Swiss bernama Samuel Cornut yang karena mencemaskan adanya bahaya minat biologis yang terlalu sepihak kepada Jean. Ia lalu membangkitkan minat Jean pada filsafat Bergson, yang dalam karyanya berjudul "L "Evolution Creatrice" yang membahas adaptasi biogis. Dalam masa itu muncul juga kegemaran Piaget untuk membaca dan dia mulai menekuni buku-buku William James, E. Kant, E. Durkheim, Darwin, H. Spencer dan lain-lain. Mulai saat itu minat Jean Piaget diperluas, dan dia mulai membaca buku-buku filsafat, agama, dan logika. Jean Piaget mengawali karirnya sebagai seorang ahli biologi, khususnya bidang malakologi. Namun ketertarikannya terhadap sains dan sejarah sains mengalahkan minatnya untuk menyelidiki siput dan kerang. Karena dia semakin larut dalam penyelidikan bagaimana proses pikiran yang bekerja dalam sains, akhirnya dia tertarik pula untuk menyelidiki apa sesunggunya pikiran itu sendiri, khususnya tahap- tahap perkembangannya. Akhirnya dia berkesempatan menamai 
bidang yang menjadi fokus penelitiannya tersebut. Dia menyebutnya dengan epistemologi genetik, yang berarti studi tentang perkembangan manusia.

Penelitian ini bila dilihat dari jenisnya termasuk kedalam kategori penelitian pustaka (Library Research), yakni suatu penelitian yang menggunakan buku-buku sebagai sumber data utamanya.Dalam hal ini, peneliti bermaksud menggali data berupa buku-buku pokok agar mampu mengungkap dan mengetahui konsep perkembangan kognitif menurut kedua tokoh yang dikomparasikan. Metode Pengumpulan Data Dalam pengumpulan data bersifat teori, digunakan metode dokumentasi dimaksudkan untuk mengumpulkan berbagai teori, pendapat serta peraturan yang berlaku dari berbagai sumber tertulis seperti, buku, skripsi, tesis, desertasi, majalah, artikel, yang bersentuhan dengan konsep perkembangan kognitif.Metode dokumentasi yang dimaksudkan yakni, umtuk menemukan data melalui penganalisaan teksteks yang berkenaan langsung dengan variabel penelitian, dalam hal ini penelitian kepustakaan (library research).

\begin{tabular}{|c|c|c|}
\hline No & Judul & Kesimpulan Pembahasan \\
\hline 1 & $\begin{array}{l}\text { Konsep Pendidikan Anak } \\
\text { Dalam Persfektif Al-Ghazali } \\
\text { (Analisis Teori Tahap-tahap } \\
\text { Perkembangan Jean Piaget) }\end{array}$ & $\begin{array}{l}\text { Penelitian ini dilakukan oleh Nurus Sa"eadah, } \\
\text { Sarjana pada Fakultas Tarbiyah Universitas } \\
\text { Islam Negeri Malang Jurusan Pendidikan } \\
\text { Agama Islam. Pokok pembahasa dalam } \\
\text { penelitian ini ialah mengenai pendidikan } \\
\text { anak. Dari penelitian ini terungkap bahwa Al- } \\
\text { Ghazali memiliki konsep pendidikan anak } \\
\text { yang holistic yaitu mencakup aspek spiritual, } \\
\text { moral,sosial, kognitif, dan fisik. Konsep } \\
\text { pendidikan anak persfektif Al-Ghazali } \\
\text { memiliki ketersesuaian dengan tahap-tahap } \\
\text { perkembangan Jean Piaget terlebih pada } \\
\text { materi dan metodenya. } \\
\text { Materi pendidikan menurut Al-Ghazali } \\
\text { bertahap dari yang berupa materi ilmu prakti } \\
\text { hingga materi yang berisi argumentasi } \\
\text { karena menurut Piaget kemampuan kognitif } \\
\text { anak berkembang dari yang paling sederhana } \\
\text { hingga yang paling rumit. Begitu pula metode } \\
\text { pendidikan berawal dari yang hanya bersifat } \\
\text { peniruan hingga metode berpikir karena } \\
\text { perkembangan kognitif annak berkembang } \\
\text { dari yang hanya mampu meniru hingga yang } \\
\text { mampu berpikir abstrak. Dengan demikian } \\
\text { maka periodisasi perkembangan anak Al- } \\
\text { Ghazali memiliki ketersesuaian dengan tahap- } \\
\text { tahap perkembangan Jean Piaget. }\end{array}$ \\
\hline
\end{tabular}

2 Peran Kepribadian Peserta

Penelitian ini dilakukan oleh Nurul Hikmah Didik (Studi Komparasi Pemikiran Al- Ghazali dan Sofyan, Sarjana pada Fakultas Tarbiyah dan Keguruan Universitas Islam Negeri Jean Piaget) Walisongo Semarang Jurusan Pendidikan Agama Islam. Pokok bahasan dalam penelitian ini ialah mengkaji tentang peran kepribadian guru dalam membentuk kepribadian peserta didik. Penelitian ini mengungkap bahwa Al-Ghazali dan Jean 
Piaget sama-sama mengakui bahwa manusia terdiri dari unsure jasad dan rasio, bedanya Jean Piaget tidak mengakui unsur-unsur manusia sudut pandang psikosufistik AlGhazali seperti ruh, qalb, dan nafs sehingga secara otomatis Jean Piaget mengabaikan kebutuhan unsure-unsur tersebut. AlGhazali memandang guru berperan sebagai pembimbing spiritual dan role model, Sedangkan kepribadian guru atas konsep perkembangan moral Jean Piaget ialah seberapa besar peran guru untuk menyediakan area belajar baru agar peserta didik dapat berpikir dan bersikap secara otonomi atas tuntutan lingkungannya. Manfaat penelitian ini ialah untuk pembentukan kepribadian peserta didik persfektif islam yang diintegrasikan dengan psikologi modern supaya didapat pengembangan yang komprehensif terutama secara epistemologi. ${ }^{95}$

\begin{tabular}{ll}
\hline Data & \multicolumn{2}{c}{ Sumber Data } \\
\hline Data Pertama: Konsep Kognitif & Sumber data atau teori Al-Ghazali \\
(akal) Al-Ghazali & tentang konsep akal terdapat pada \\
& karya Al-Ghazali yakni Ihya \\
& Ulumuddin dan karya Muhammad \\
& Yasir Nasution yang berjudul Manusia \\
& Menurut Al-Ghazali. Sebagai rujukan \\
& dasar peneliti sebuah Karya Al-Ghazali \\
& yang diterjemahkan oleh Ibnu Ibrahim \\
& Ba'adillah, diterbitkan oleh Republika. \\
& Dalam hal ini, konsep Aq'l Al-Ghazali \\
& terdapat pada buku tersebut yang \\
& terletak pada halaman 8. Selain itu \\
& untuk memperkuat data atau teori, \\
& konsep akal juga terdapat pada karya \\
Muhammad Yasir Nasution yang & diterbitkan oleh Rajawali. Dalam hal \\
& ini, konsep akal tersebut terdapat pada \\
halaman 70-76. \\
\hline Sumber teori atau data Jean Piaget \\
tentang kognitif peneliti rujuk dari \\
karya Jean Piaget yang berjudul Antara \\
Tindakan Dan Pikiran. \\
\hline \\
\hline (akal) Jean Peaget
\end{tabular}

Dalam membedakan metodologi kedua tokoh tersebut, peneliti menamakan metodologi Al-Ghazali sebagai metodologi "rasio" yang bersumber dari "wahyu", dan metodologi Jean 
Piaget sebagai metodologi "rasio murni". Pada dasarnya, kedua tokoh tersebut secara eksplisit tidak menamakan metodologi mereka dengan istilah yang digunakan oleh peneliti, akan tetapi dari pengamatan peneliti melalui studi yang cermat dengan melihat cara kedua tokoh dalam menjelaskan ide-ide pemikiran mereka, sehingga peneliti dapat menyimpulkan pengamatan yang sedemikian rupa dan selanjutnya hal itu dapat membantu peneliti dalam mengklasifikasikan pendekatan mereka kedalam dua metode yang berbeda.

Pertama, yang peneliti maksud dengan metode rasio yang bersumber dari wahyu yaitu usaha untuk membuktikan dan memperkuat keyakinan melalui cara-cara yang logis dan rasional. Tindakan ini dilakukan sebagai upaya penyelesaian terhadap berbagai permasalahan dengan berlandaskan pada ayat-ayat Al-Quran yang sesuai dengan topik permasalahan. Jadi metode rasio yang bersumber dari wahyu adalah sebuah prosedur yang dijalankan melalui cara yang rasional dengan menjadikan Al- Qur'an sebagai landasan dalam berpikir. Kedua, adalah metode rasio murni sebagai tolak ukur dalam memandang sesuatu hal. Dalam persfektif Piaget, metode ini digunakannya secara tunggal, artinya dalam proses berpikir Piaget hanya menggunakan cara-cara yang logis dan rasional tanpa adanya pengaruh teologis. Pada tempat ini, Al-Ghazali menyatakan bahwa manusia untuk memilih perbuatan yang baik dari yang buruk memerlukan al-ta"yid (penguatan) dari Tuhan, yaitu bagian dari inayat dan taklif dari Tuhan, yang berkaitan dengan perbuatan manusia. Inayat Tuhan adalah pemeliharaan Tuhan terhadap segala yang ada dalam keadaan yang terbaik sesuai dengan ilmu-Nya. Al-Ghazali berpendapat bahwa

pemeliharaan itu tidak hanya bersifat umum, tetapi juga bersifat khusus; Tuhan mengarahkan setiap orang dalam perbuatannya. Bahwa ia melihat pemeliharaan tuhan itu tidak hanya bersifat umum dapat diketahui dari hubungan inayat dengan perbuatan manusia dalam bentuk ta"yid. Perbuatannya dalam wujudnya bersifat partikular. Apabila ta "yid berhubungan dengan perbuatan, maka ia berhubungan dengan sesuatu yang khusus, Tuhan mempunyai peranan yang kuat dalam perwujudan perbuatan itu, karena, Al-Ghazali mentakan bahwa ikhtiyar tidak akan terwujud tanpa ta"yid.

Piaget, yang lahir dari lingkungan rasionalitas, tentunya menggunakan rasio sebagai alat analisisnya dalam menemukan suatu hal. Melalui rasio murninya inilah kemudian ia mengawali ketertarikannya terhadap ilmu alam. Piaget mengawali karirnya sebagai seorang biolog, khususnya dalam bidang malakologi.Akan tetapi ketertarikannya terhadap sains dan sejarah sains mengalahkan minatnya untuk menyelidiki siput dan kerang. Karena dia semakin larut dalam penyelidikan bagaimana proses pikiran yang bekerja dalam sains, akhirnya dia tertarik pula untuk menyelidiki apa sesungguhnya pikiran itu sendiri,khususnya tahap-tahap perkembangannya. Akhirnya dia menamai fokus penelitiannya tersebut dengan istilah epistemologi genetik, yang berarti studi tentang perkembangan manusia.

\section{Kesimpulan}

Adapun kesimpulan dari pemaparan penelitian ini dapat disimpulkan bahwa, Konsep perkembangan kognitif (akal) menurut Al-Ghazali terbagi menjadi empat tahapan yakni: al,, aql al-hayulani, al-,, aql bi al-malakat, al-,, aql bi al-fi" il, dan al-,, aqlal-mustafad. Sedangkan konsep perkembangan kognitif (akal) menurut Jean Piaget terbagi juga kedalam empat tahapan yakni: sensoris- motoris, pra-operasional, kongkret-operasional, dan formal-operasional. Persamaan konsep perkembangan kognitif (akal) menurut Al-Ghazali dan Jean Piaget yakni terdapat pada tahapan perkembangan yang terbagi kedalam empat tahapan. Selain itu, pandangan kedua tokoh juga mempunyai hubungan atau titik temu yang terdapat pada aspek kemampuan dari tiap tahapan yang dilewati pada proses perkembangan kognitif (akal). Perbedaan konsep perkembangan kognitif (akal) menurut Al-Ghazali dan Jean Piaget terdapat pada metodologi sebagai dasar pemikiran keduanya. Al-Ghazali mendasari pemikirannya kepada rasio yang bersumber dari wahyu sedangkan Jean Piaget meletakkan dasar 
pemikirannya pada rasio murni. Selain itu, perbedaan konsep perkembangan kognitif (akal) menurut kedua tokoh juga terdapat pada penggunaan istilah. Al-Ghazali menggunakan istilah $a q l$ sedangkan Jean Piaget menggunakan istilah kognitif.

\section{Daftar Pustaka}

Bahasa, P. (2005). Kamus Besar Bahasa Indonesia (3rd ed.). Jakarta: Balai Pustaka.

Chaplin, J. P. (1997). Kamus Lengkap Psikologi, Terj. Kartini Kartono (4th ed.). Jakarta: Raja Grafindo Persada.

Ibda, F. (2015). Perkembangan Kognitif: Teori Jean Piaget. INTELEKTUALITA, 3(1), 27-38. Ihalauw, J. J. O. I. (2008). Konstruksi Teori: Komponen dan Proses. Jakarta: PT. Grasindo.

Janna, S. R. (2013). Konsep Pendidikan Anak Dalam Perspektif Al-Ghazali (Implikasinya Dalam Pendidikan Agama Islam). Jurnal Al-Ta'dib, 6(2), 41-55.

Reber, A. S., \& Reber, E. S. (2010). Kamus Psikologi, Ter. Yudi Santoso. Yogyakarta: Pustaka Pelajar.

Solichin, M. M. (2006). Belajar Dan Mengajar Dalam Pandangan Al-Ghazâlî. Adris: Jurnal Pendidikan Islam (e-Journal), 1(2), 138-153.

Suparno, P. (2001). Teori Perkembangan Kognitif Jean Piaget. Penerbit kanisius. 